pionic acid concentration went down to $3.7 \mathrm{mg} / 1$ during fasting. After muscular exercise during an hour, we observed a non significant lowering of the acetic acid concentration from 120 to $96 \mathrm{mg} / \mathrm{l}$. Most of the horses showed a pronounced lowering of acetic acid concentration, others an increase. In other respects, individual differences were very marked.

VFA concentrations in peripheral blood were therefore much variable according to the individual, diet, time spent from the last meal and muscular work. Further investigations are performed to specify these variations.

\title{
EFFETS SUR LE PH INTRA GASTHIQUE DE L'INCORPORATION DE LACTOSÉRUM SEC DANS LA RATION DU PORC EN FINITION
}

\author{
J. P. LAPLACE et C. FEVRIER * \\ Laboratoire de Physiologie de la Nutrition, \\ * Station de Recherches sur l'Élevage des Porcs, \\ Centre national de Recherches zootechniques, I. N. R. A., \\ 78350 Jouy en Josas
}

A côté des facteurs mécaniques dont l'importance est apparue au travers de travaux antérieurs (I-2), divers facteurs physicochimiques, dont l'acidité du chyme parvenant au duodénum, interviennent classiquement dans le contrôle de I'évacuation gastro-duodénale.

L'objet de ce travail est l'étude du $\mathrm{pH}$ prépylorique lors de distribution d'un aliment de finition comportant $40 \mathrm{p}$. Ioo de lactosérum sec, acide ou doux, par rapport aux variations observées avec des aliments standard de croissance ou de finition.

Six porcs de race Large White pesant entre 60 et $68 \mathrm{~kg}$, porteurs d'un tube gastrique (introduction de l'électrode stomacale) et d'une canule cæcale (introduction de l'électrode de référence) ont été utilisés au cours de séances d'enregistrement d'une durée maximum de 8 heures. L'électrode stomacale localisée $2 \mathrm{~cm}$ au-dessus du pylore permet l'enregistrement continu du pH sur polygraphe.

Quel que soit l'aliment utilisé, le pH intragastrique chez l'animal encore à jeûn le matin est compris entre $I, 5$ et 3,0 . Pour un aliment de finition standard, le premier repas (à $9 \mathrm{~h}$ ) provoque une remontée du $\mathrm{pH}$ de l'ordre de 2,2 à 2,4 unités $\mathrm{pH}$, au bout d'un délai variable après le début du repas. Le $\mathrm{pH}$ redescend à environ 2,5 en l'espace de $2 \mathrm{~h}$. Les autres repas de la journée induisent une remontée plus faible ( $\mathrm{I}$ unité $\mathrm{pH}$ ).

Un aliment de croissance standard provoque au I er repas une remontée toujours précoce et très rapide du $\mathrm{pH}$, d'une amplitude de 3 , voire 4 unités $\mathrm{pH}$. La décroissance ultérieure est nettement plus lente. Les autres repas de la journée n'entraînent aucune remontée de la courbe. L'ingestion d'aliments lactosérum entraîne une remontée du $\mathrm{pH}$ très précoce ; tous les repas provoquent une augmentation (à l'instar du finition standard). Dans le cas du lactosérum acide cette remontée est, lors du premier repas, aussi ample et rapide que pour l'aliment croissance standard. Dans le cas du lactosérum doux elle s'effectue en 2 ou 3 vagues, la valeur maximum n'étant atteinte qu'en 30 à $70 \mathrm{mn}$. Des reflux duodénogastriques sont très fréquemment observés chez les animaux recevant des aliments lactosérum. 
La gamme dans laquelle évolue le $\mathrm{pH}$ intragastrique, quel que soit le lactosérum utilisé, est absolument superposable à celle observée pour des aliments standard de croissance ou de finition. Les particularités identifiant les régimes concernent principalement le délai, la rapidité et l'amplitude de la variation de $\mathrm{pH}$ induite par le premier repas de la journée.

\section{RÉFÉRENCES BIBLIOGRAPHIQUES}

(I) Laplace J. P., Tomassone R., 1970. Ann. Zootech., 19, 303-332.

(2) Laplace J. P., I972. Rec. Med. Vet., 148, 37-6I.

\section{SUMMARY}

\section{EFFECT OF DRY WHEY INCORPORATION INTO FINISHING PIG DIETS ON THE INTRAGASTRIC PH}

Besides the mechanical factors demonstrated in previous studies ( $\mathrm{t}-2)$ various physicochemical factors, such as the acidity of the chyme reaching the duodenum, usually intervene in the control of the gastro-duodenal emptying.

The aim of the present work is to study the prepyloric $\mathrm{pH}$ after feeding of a finishing ration containing $4^{\circ}$ p. Ioo dry whey, sour or sweet, as related to the variations observed with standard growing or finishing feeds.

Six Large White pigs weighing between 60 and $68 \mathrm{~kg}$, fitted with a gastric tube (introduction of the stomachal electrode) and with a caecal cannula (introduction of the control electrode) were used during sessions of recordings lasting to a maximum 8 hours. The stomachal electrode located $2 \mathrm{~cm}$ above the pylorus allows a continuous recording of $\mathrm{pH}$ with a polygraph.

Whatever the feed used, the intragastric $\mathrm{pH}$ in the still fasting animal (in the morning) ranged between $\mathrm{I} .5$ and 3.0. For a standard finishing diet the first meal $(9 \mathrm{a} . \mathrm{m}$.) induced raising of $\mathrm{pH}$ of about 2.2. to $2.4 \mathrm{pH}$ units after variable intervals following the beginning of the meal. The $\mathrm{pH}$ decreased down to about 2.5 within 2 hours. The other meals of the day led to a smaller increase (I pH unit).

A standard growing feed induced, with the Ist meal, an always early and very rapid $\mathrm{pH}$ increase of 3 and even $4 \mathrm{pH}$ units. The further decrease was definitely slower. The other meals of the day did not lead to any increase of the curve. Whey intake caused a very early raising of the $\mathrm{pH}$; all the meals brought about an increase (like the finishing standard diet). In the case of sour whey this increase, at the first meal, was as large and rapid as for the growing standard feed. In the case of sweet whey, it occurred in 2 or 3 waves, the maximum value being only reached within 30 to $70 \mathrm{mn}$. Duodenogastric reflexes were noted very often in the whey fed animals.

The range within which intragastric $\mathrm{pH}$ varied, whatever the kind of whey used, was absolutely comparable to that observed with growing or finishing standard diets. The characteristics identifying the diets mainly concerned the delay, rapidity and magnitude of $\mathrm{pH}$ variation induced by the first meal of the day. 